\title{
EFFECT OF DIFFERENT QUANTITIES OF VELVETBEAN GREEN MANURE ON CORN YIELDS IN PUERTO RICO
}

\section{J. A. Bonnet and M. A. Lugo-López}

\section{INTRODUCTION}

Velvetbeans Stizolobium deeringianum, a legume, when added to acid soils of Puerto Rico, both in the presence and in the absence of lime and phosphorus, gave higher significant yields of green manure than three other legumes tried: Crotalaria Crotalaria striata, cowpeas Vigna sinensis, and soybeans Soja $\max$, Otootan variety $(1)^{2}$. Green manure from velvetbeans, 4 tons of limestone, and 100 pounds of $\mathrm{P}_{2} \mathrm{O}_{5}$ as superphosphate, significantly increased the yields of sweetpotatoes and corn in two acid soils of Puerto Rico (2). A 30-month rotation sequence of two crops of the four above-mentioned legumes, one of sweetpotatoes, two of the legumes, and one of corn was studied from June 1944 to November 1947, inclusive, in both soils. The equivalent of 4.5 to 6 tons of green manure per acre was incorporated into each soil per crop of velvetbeans, or a total of 9 to 12 tons from the crops of velvetbeans, before planting sweetpotatoes and corn, respectively.

This paper reports data obtained on the effect on corn yields of velvetbean green manure when incorporated into the soil in smaller and in larger quantities than those previously used, either as a mulch or turned under. The work did not include a comparison between turning under the green manure or leaving it as a mulch.

\section{EXPERIMENTAL PROCEDURE}

The sites selected for the field work lie within the same general area where the previous work with legume and food crops was done $(1,2)$ : Río Piedras in the north at $18^{\circ} 24^{\prime} \mathrm{N}$. latitude and $63^{\circ} 03^{\prime} \mathrm{W}$. longitude, and Mayagüez, 150 miles away to the west, at $18^{\circ} 12^{\prime} \mathrm{N}$. latitude and $67^{\circ} 09^{\prime}$ W. longitude. Two 1-acre fields of Fajardo clay were selected in the García Méndez farm in Río Piedras, and two of Catalina clay in the Las Ochenta farm at Mayagüez. Applications of superphosphate were made to the acid plots at the rate of 100 pounds of $\mathrm{P}_{2} \mathrm{O}_{5}$ per acre and of ground limestone at the rate of 4 tons per acre before the velvetbeans were planted.

For the field experiments four-tenths of an acre was selected at Río Piedras and two-tenths at Mayagüez. The fields were planted with velvetbeans following the contour lines and divided into plots one-hundredth of an

${ }^{1}$ Soil Scientist, Head of Department, and Associate Soil Scientist, respectively, Agricultural Experiment Station, University of Puerto Rico, Río Piedras, P. R.

${ }^{2}$ Numbers in parentheses refer to Literature Cited, p. 101. 
acre in area. Adjacent areas were planted to velvetbeans to supply enough green manure for the differential treatments.

The velvetbean seeds were planted at a 6 -inch distance within rows placed 1-foot apart. After the legume crop was harvested, the following treatments were used: Check; 5 and 10 tons of green manure per acre, respectively, at Mayagüez; and a fourth test with 25 tons of green manure per acre at Río Piedras. Six replicates were used at Mayagüez and nine at Río Piedras. At each location the green manure was left as a mulch in one field and turned under in a second.

Two crops of corn followed the velvetbean crop at Río Piedras and one at Mayagüez. The plots at Río Piedras were hoed to a depth of about 4 inches before planting the second corn crop. Seeds of the Mayorbela variety were planted in hills, 18 -inch apart with a 3 -foot distance between rows. Four seeds were placed in each hole and covered with soil. The germinated plants were thinned to two seedlings per hole. The corn plants were sprayed several times with 3 pounds of 50-percent DDT in 100 gallons of water per acre to control the caterpillar Laphygma frugiperda. A bait of phosphorus paste with corn flour was used for rat control. Each corn crop received an application of 240 pounds $\mathrm{K}_{2} \mathrm{O}$ per acre as muriate of potash.

Surface soil samples were taken at a 6 -inch depth from each plot used for each crop at Río Piedras after the second corn crop was harvested. Nitrogen, organic matter, and $\mathrm{pH}$ were determined on these soil samples.

\section{RESULTS AND DISCUSSION}

The rotation sequence, dates of planting and harvesting, and age of the velvetbeans and corn crops at Río Piedras and Mayagüez are reported in table 1 . The mean yields of the corn crops and the least significant differences for the different levels of green manure mulched or turned under are reported in table 2 .

The mean green weight for the crop of velvetbeans grown at Río Piedras was 4.5 tons to the acre. At Mayagüez the yield ranged from 0.7 to 5.2 tons to the acre with a mean of 2.8 tons. The Río Piedras crop was normal when compared to the previous four crops raised $(1,2)$ at the same general location. However, the Mayagüez crop was rather poor even when sufficient lime and phosphorus was supplied.

The analyses of the total sum of squared deviation of dry shelled corn yields for the two corn crops at Río Piedras and the one at Mayagüez are reported in table 3 .

There was a highly significant difference between treatments for the corn crop in Catalina clay at Mayagüez; 5 tons of green manure notably increased the corn yields (table 2 ) when left as a mulch or turned under. The interaction between treatments and fields at Mayagüez was highly signifi- 
cant; 10 tons of green manure turned under significantly increased the yield of corn, but no significant increase was obtained in the mulched field. Bonnet et al. (2) found significant responses in the yield of sweetpotatoes and corn in two other fields of Catalina clay when 9 tons of velvetbean green manure from two consecutive legume crops were applied with 4 tons of limestone and 100 lbs. $\mathrm{P}_{2} \mathrm{O}_{5}$ per acre.

TABLE 1.-Rotation sequence, dates of planting and harvesting, and age of crops at Rio Piedras and Mayagüez

\begin{tabular}{|c|c|c|c|c|c|}
\hline Crop & $\begin{array}{l}\text { Crop in the } \\
\text { rotation }\end{array}$ & Location & Date of planting & Date of harvesting & Age \\
\hline \multirow{3}{*}{ First } & \multirow{3}{*}{ Velvetbeans } & & & & Days \\
\hline & & SRío Piedras & Dec. 4,1947 & Feb. 17-20, 1948 & 79 \\
\hline & & Mayagüez & Apr. 30,1948 & Sept. 15, 1948 & 108 \\
\hline \multirow{2}{*}{ Second } & \multirow{3}{*}{$\begin{array}{l}\text { Corn } \\
\text { do. }\end{array}$} & $\{$ Rio Piedras & May 12-14, 1948 & Aug. 18-19, 1948 & 96 \\
\hline & & Mayagüez & Sept. 28,1948 & Dec. 22,1948 & 86 \\
\hline Third & & Río Piedras & Dec. $9-10,1948$ & Mar. 28, 1949 & 107 \\
\hline
\end{tabular}

TABLE 2.-Mean yields in hundredweights to the acre and least significant differences for dry shelled corn at different levels of green manure, mulched or turned under in different fields

\begin{tabular}{|c|c|c|c|c|c|c|}
\hline \multirow{3}{*}{ Treatment } & \multirow{2}{*}{\multicolumn{2}{|c|}{$\begin{array}{l}\text { Mayagüez } \\
\text { crop 1 }\end{array}$}} & \multicolumn{4}{|c|}{ Río Piedras } \\
\hline & & & \multicolumn{2}{|c|}{ Crop 1} & \multicolumn{2}{|c|}{ Crop 2} \\
\hline & Mulched & $\begin{array}{l}\text { Turned } \\
\text { under }\end{array}$ & Mulched & $\begin{array}{l}\text { Turned } \\
\text { under }\end{array}$ & Mulched & $\begin{array}{l}\text { Turned } \\
\text { under }\end{array}$ \\
\hline Check, no green manure. & 4.0 & 1.5 & 14.3 & 22.1 & 12.7 & 11.4 \\
\hline 5 tons green manure.... & 15.6 & 16.6 & 14.6 & 21.0 & 12.2 & 12.4 \\
\hline 10 tons green manure. . & 16.0 & 20.6 & 16.0 & 23.2 & 13.6 & 10.4 \\
\hline 25 tons green manure........ & - & - & 17.9 & 23.1 & 14.6 & 13.5 \\
\hline \multicolumn{7}{|l|}{$\begin{array}{l}\text { L.S.D. between means of two } \\
\text { treatments: }\end{array}$} \\
\hline at 5 -percent point....... & 2.9 & 2.4 & 4.7 & 4.0 & 4.8 & 3.7 \\
\hline at 1 -percent point. & 4.2 & 4.2 & 6.4 & 5.4 & 6.5 & 5.1 \\
\hline
\end{tabular}

There was no significant difference between treatments for the two corn crops in Fajardo clay at Río Piedras. The soil content of 0.23 percent of $\mathrm{N}$ (table 4) was sufficient to produce the maximum corn yield obtained. The mean organic-matter content of this soil was 3.4 percent. Bonnet et al. (2) found significant responses in the yield of sweetpotatoes and corn in two other fields of the acid Fajardo clay when 12 tons of velvetbean green manure from two consecutive legume crops were applied with 4 tons of limestone and $100 \mathrm{lbs} . \mathrm{P}_{2} \mathrm{O}_{5}$ per acre. That field contained 0.17 percent of 
nitrogen or 0.06 percent less than the field of Fajardo clay where the velvetbean green manure did not significantly increase the corn yields. The organic-matter content of this soil was about half of that, or 1.7 percent.

TABLE 3.-Analyses of the total sum of squared deviation for dry shelled corn yields

\begin{tabular}{|c|c|c|c|c|c|c|}
\hline $\begin{array}{l}\text { Crop } \\
\text { No. }\end{array}$ & Place & Source of variation & $\begin{array}{c}\text { Degrees of } \\
\text { freedom }\end{array}$ & $\begin{array}{l}\text { Sum of } \\
\text { squares }\end{array}$ & Variance & $F$ values \\
\hline \multirow{8}{*}{1} & \multirow{7}{*}{ Río Piedras } & Total & 71 & $2,054.76$ & $\ldots \ldots$ & $\ldots \ldots$ \\
\hline & & Blocks & 16 & 361.76 & $\ldots \ldots$ & $\ldots \ldots$ \\
\hline & & Fields & 1 & 802.47 & $\ldots \ldots$ & $\ldots \ldots$ \\
\hline & & Treatments & 3 & 83.07 & 27.69 & 1.68 \\
\hline & & Treatments $\times$ fields & 3 & 17.93 & 5.98 & .36 \\
\hline & & Error & 48 & 789.53 & 16.45 & $\ldots \ldots$ \\
\hline & & Total & 35 & $1,942.22$ & $\ldots \ldots$ & $\ldots \ldots$ \\
\hline & \multirow{5}{*}{ Mayagüez } & Blocks & 10 & 60.63 & $\ldots \ldots$ & $\ldots \ldots$ \\
\hline \multirow{4}{*}{1} & & Fields & 1 & 9.51 & $\ldots \ldots$ & $\ldots \ldots$ \\
\hline & & Treatments & 2 & $1,683.98$ & 841.99 & $175.40^{1}$ \\
\hline & & Treatments $\times$ fields & 2 & 92.16 & 46.08 & $9.60^{1}$ \\
\hline & & Error & 20 & 95.94 & 4.80 & $\ldots \ldots$ \\
\hline \multirow{6}{*}{2} & \multirow{6}{*}{ Río Piedras } & Total & 70 & $2,674.62$ & $\ldots \ldots$ & $\ldots \ldots$ \\
\hline & & Blocks & 16 & $1,675.94$ & $\ldots \ldots$ & $\ldots \ldots$ \\
\hline & & Fields & 1 & 31.30 & $\ldots \ldots$ & $\ldots \ldots$ \\
\hline & & Treatments & 3 & 47.53 & 15.80 & .83 \\
\hline & & Treatments $\times$ fields & 3 & 20.54 & 6.80 & .36 \\
\hline & & Error & 47 & 899.40 & 19.14 & $\ldots \ldots$ \\
\hline
\end{tabular}

${ }^{1}$ Highly significant.

TABLE 4.-Chemical data on the surface-soil samples taken at Rio Piedras 13 months after the treatment differentials were established and after the second corn crop was harvested

\begin{tabular}{|c|c|c|c|c|c|c|c|c|}
\hline \multirow[b]{2}{*}{ Treatment } & \multicolumn{4}{|c|}{ Mulched } & \multicolumn{4}{|c|}{ Turned under } \\
\hline & $\mathrm{pH}$ & $\begin{array}{c}\text { Total } \\
\text { nitro- } \\
\text { gen }\end{array}$ & $\begin{array}{l}\text { Organic } \\
\text { matter }\end{array}$ & $\begin{array}{l}\mathrm{C} / \mathrm{N} \\
\text { ratio }\end{array}$ & $\mathrm{pH}$ & $\begin{array}{c}\text { Total } \\
\text { nitro- } \\
\text { gen }\end{array}$ & $\begin{array}{l}\text { Organic } \\
\text { matter }\end{array}$ & $\begin{array}{l}\mathrm{C} / \mathrm{N} \\
\text { ratio }\end{array}$ \\
\hline & & Percent & Percent & & & Percent & Percent & \\
\hline Check, no green manure. & 5.0 & 0.23 & 3.9 & 10.1 & 4.9 & 0.24 & 2.9 & 7.0 \\
\hline 5 tons green manure.... & 4.9 & .16 & 3.8 & 17.7 & 5.0 & .25 & 3.2 & 7.4 \\
\hline 10 tons green manure... & 5.1 & .17 & 3.6 & 18.9 & 5.4 & .25 & 2.9 & 6.6 \\
\hline 25 tons green manure. . & 4.9 & .21 & 3.9 & 15.9 & 5.0 & .24 & 3.5 & 8.4 \\
\hline
\end{tabular}

The second corn crop was planted after leaving the land fallow for a 4month period (table 1). This crop was scheduled to be planted early after harvesting the first one, but the continuous rains throughout the fall caused a considerable delay. The second crop was intended to measure the residual effects, if any, of the additions of green manure before planting the first 
corn crop. The second crop suffered a heavy reduction in the number of plants from a severe rat attack. Instead of 160 plants in each plot, the population varied widely from a minimum of 20 to 50 to a maximum of 131 to 152 . A covariance analysis was made to correct yield variations attributable to stand but the reduction in sum of squares for treatments was not significant. The residual effect of the green manure did not raise the yields of the second corn crop.

The mean values for the soil samples taken at a 6 -inch depth in the acid Fajardo clay at Río Piedras, including $\mathrm{pH}$, nitrogen, organic matter, carbon-nitrogen ratio, representative of the mulched and turned-under treatments, and the least significant differences, are reported in table 4 . In general, no significant differences were obtained between each of the above mean values for the treatments, but the nitrogen content was significantly higher in the check plots than in the plots mulched with 5 or 10 tons of green manure. The active microorganisms used about 0.07 percent of the soil nitrogen in decomposing the 5 and 10 tons of green manure but with the 25 tons there was no apparent change in the soil nitrogen.

\section{SUMMARY}

Different levels of a leguminous green manure from velvetbeans, either left as a mulch or turned under, were added to two acid soils in Río Piedras and Mayagüez, Puerto Rico, that received 4 tons of ground limestone and 100 pounds $\mathrm{P}_{2} \mathrm{O}_{5}$ per acre. The objective was to study the effect of the manure upon the yield of corn fertilized with 240 pounds of $\mathrm{K}_{2} \mathrm{O}$ per acre.

Five tons of the green manure increased the corn yields in Catalina clay at Mayagüez whether left as a mulch or turned under. However, 10 tons increased the yields when turned under but not when left as a mulch.

There was no significant difference in corn yields in acid Fajardo clay at Río Piedras whether 5,10 , and 25 tons of green manure were used. But significant yield responses of sweetpotatoes and corn were obtained before (2) in two other fields of this soil. The difference in behavior is explained on the basis of the higher nitrogen and organic-content of the soil in the field where responses were not obtained.

The residual effect of the green manure did not raise the yields of a second corn crop at Río Piedras.

\section{RESUMEN}

A dos suelos ácidos de Puerto Rico, a los cuales se les había añadido cal y ácido fosfórico $\left(\mathrm{P}_{2} \mathrm{O}_{5}\right)$, a razón de 4 toneladas y 100 libras por acre, respectivamente, también se les añadió distintos niveles de un abono verde de habichuelas terciopelo. El abono verde se enterró en un campo y se dejó como capa mullidora (mulch) en otro campo. 
El objetivo del trabajo fué estudiar los efectos del abono verde sobre los rendimientos del maíz, el cual había sido abonado con 240 libras de potasa $\left(\mathrm{K}_{2} \mathrm{O}\right)$ por acre.

Cinco toneladas del abono verde, indistintamente, aumentaron los rendimientos del maíz en una arcilla Catalina en Mayagüez, cuando se enterró o se usó como capa mullidora.

Sin embargo, 10 toneladas de la misma clase de abono verde sólo aumentó los rendimientos cuando se enterró con arado, siendo desatendibles los efectos al dejarse como capa mullidora.

No hubo diferencias significativas en los rendimientos del maíz en la arcilla ácida Fajardo en Río Piedras, aún usando 5, 10 y 25 toneladas del abono verde. Sin embargo, anteriormente se habían registrado aumentos en los rendimientos de batatas y maíz, en dos parcelas del mismo tipo de suelo en el mismo sitio, lo que da a entender que el contenido de nitrógeno y materia orgánica en el terreno habían llegado ya a su estado óptimo, antes de establecer el experimento.

El efecto residual del abono verde, tampoco aumentó los rendimientos de una segunda cosecha de maíz que se sembró en el mismo sitio en Río Piedras.

\section{LITERATURE CITED}

1. Bonnet, J. A., Telford, E. A., Mariota, F., and Tirado-Sulsona, P., Effect of lime and phosphorus on the yield of four leguminosae in two acid soils of Puerto Rico, J. Agr. Univ. P. R. 29(2) 47-56, 1945.

2. Bonnet, J. A., Tirado-Sulsona, P., and Abruña, F., Effect of lime-phosphorus and green manure on sweetpotatoes and corn grown in acid soils, J. Agr. Univ. P. R. 31(4) 303-321, 1947. 